\title{
Crop diversification analysis on red pepper dominated smallholder farming system: evidence from northwest Ethiopia
}

\author{
Abebe Birara Dessie ${ }^{1 *}$, Tadie Mirie Abate $^{1}$, Taye Melese Mekie $^{1}$ and Yigrem Mengist Liyew ${ }^{2}$
}

\begin{abstract}
Background: Ethiopia is the homeland of various crops due to its diverse and suitable agro-ecological zones. As a result, smallholder farmers grow multiple crops on a small piece of land both for consumption and commercial purposes in different portions of Ethiopia, including the northwestern part of the country. However, crop diversification status and extent of farmers were not well understood. Therefore, this study examined determinants of crop diversification in a pepper-dominated smallholder farming system in northwest Ethiopia.

Methods: Primary data was collected through a semi-structured interview schedule administered on 385 crop producers selected using a systematic random sampling technique. Moreover, the survey was supplemented by using secondary data, focus group discussions, and key informant interviews. Methods such as the descriptive, inferential statistics, and econometrics model were used for analyzing the data.

Results: The average crop diversification index was 0.77 , and most smallholder farmers (92.46\%) used crop diversification as a strategy for risk reduction, nutritional improvement, consumption, and commercial needs. Moreover, the Tobit model result revealed that the status and intensity of crop diversification were significantly influenced by farmland, sex, age, land fragmentation, distance to development center, market distance, and non-/ off-farm income participation.

Conclusion: Generally, most farm households used crop diversification as a norm and best strategy for minimizing risk, income source, nutritional and livelihood improvement. Therefore, crop producers, agricultural experts, the Ethiopian government, and partner organizations should give special attention to extension service, market, and infrastructure development to enhance the role of agricultural diversification for households.
\end{abstract}

Keywords: Crop diversification, Herfindahl index, Household, Tobit model, Ethiopia

\section{Background}

In most African countries, agricultural sectors are highly dependent on rain and influenced by climate change and variability such as seasonal dynamics, drought, high temperatures, very low humidity and precipitation. Consequently, low crop yields, lessening soil fertility, high environmental degradation, and augmented agricultural risks are some of the key challenges, which continue to threaten household's food security status (Makate et al. 2016).

\footnotetext{
* Correspondence: a.birara@yahoo.com

${ }^{1}$ Department of Agricultural Economics, College of Agriculture and

Environmental Science, University of Gondar, P.O. Box 196, Gondar, Ethiopia Full list of author information is available at the end of the article
}

In many developing countries including Ethiopia, most smallholder farmers struggle to attain nutritional and food security and poverty alleviation through agricultural diversification (FAO 2012; Michler and Josephson 2017). Hence, Johnston et al. (1995) and Mussema et al. (2015) defined agricultural diversification as the way of farmers growing more than one crop on a given piece of land in any year to reduce vulnerability, marketing risks, and income and biological instability. Diversification is common in every society (Barrett et al. 2001); however, its extent and effect vary from region to region and household to household within the same area (Escobal, 2001). The increasing risks of crop failure due to erratic rainfall and crop disease continue to force farmers to diversify 
their enterprise as a hedge against these risks (Acharya et al. 2012). An increment of agricultural diversification also decreased the likelihood of poor households to become below the poverty line and increased the likelihood of non-poor households to fall into poverty (Michler and Josephson 2017). Therefore, crop diversification plays a vital role in a farmer's decision-making process so as to minimize the risk of agricultural production (Davis and Schirmer 1987).

Many studies also indicated that agricultural diversification has a multiple advantages for most smallholder farmers and the functioning of ecosystems by mitigation of agricultural losses to pests and wildlife (Bommarco et al. 2013; Chaplin et al. 2011) and improving soil fertility (Lin 2011; McDaniel et al. 2014; Tiemann et al. 2015) and biodiversity (Schulte et al. 2017; Tscharntke et al. 2005), and brings about yield stability and nutrition diversity (Lin 2011). Acharya (2011) also asserted that agricultural diversification has a great role in striving for food security. Likewise, agricultural diversification plays a vital role in economic growth by enhancing productivity, household incomes, improving soil health (through crop rotation and nitrogen fixation), and sustainable intensification of agriculture (Mussema et al. 2015).

Michler and Josephson (2017) revealed that crop diversification is the best strategy for households as a source of income, risk reduction, and poverty alleviation. Crop diversification can also increase absolute yields and yield stability for a number of crops and thus increase household income (Abson et al. 2013; Demissie and Legesse 2013; Makate et al. 2016; Njeru 2016). However, Burchfield and de la Poterie (2018) found that many farmers are not willing and able to diversify an enterprise because of the nature of their fields, elevation, soil quality, irrigation infrastructure, and relative position within an irrigation system. Likewise, the unsuitability of the local environmental condition is the main factor which prevented farmers from crop diversification (McDaniel et al. 2014).

Moreover, Ashfaq et al. (2008) revealed that crop diversification levels were influenced by various socioeconomic and institutional factors such as land size, age, education, farming experience, and off-farm income of the farmer, the distance of the farm from the main road and from the main market, and farm machinery ownership. Nuru and Seebens (2008) also found that proximity to a town, access to road, education, liquid wealth, and irrigation access as the significant factors affected crop choices in northern Ethiopia. Furthermore, Mussema et al. (2015) confirmed that crop diversification decisions of the households were significantly influenced by land size, income from sale of grain, walking time to the farm, distance from the district, access to be all-weather, market information, extension service, proportion fertile plots, and number of plots.
In Ethiopia, almost all smallholder farmers depend on the rising and growing of different types of enterprises on a given farming land for their nutritional and livelihood improvement. Farmers in general involved in a variety of enterprises, particularly diversifying crops and livestock. Unlike in commercial farming systems, farmers in subsistence farming used crop diversification as methods for reducing vulnerability, marketing risks, income instability, and food insecurity by cultivating varieties of crops on a given piece of land. Despite agriculture is the main source of livelihood for most Ethiopian smallholder farmers, not much work has been done in northwestern Ethiopia on what factors determine smallholder farmer's decision and extent to diversify their enterprise to maximize their profit and minimize the risk of crop failures. Hence, based on the above statement, the study was intended to empirically answer the following key question: what factors affect the decision and extent of crop diversification by smallholder farmers? The findings of this study can reduce the information gap on agricultural diversification and contributing to work better on production to improve nutrition, income stability, food security, and poverty reduction for most smallholder farmers.

\section{Methods \\ Description of study area}

The study was conducted in North Gondar Zone, Amhara region of Ethiopia. The zone is located in the northwest of Ethiopia and $738 \mathrm{~km}$ far from the capital city of the country. The capital city of the zone is Gondar City which located at $12^{\circ} 35^{\prime} 60.00^{\prime \prime} \mathrm{N}$ latitude and $37^{\circ} 28^{\prime} 0.01^{\prime \prime} \mathrm{E}$ longitudes with a mean altitude of 2133 masl. In the zone, the main sources of livelihood for households are crop production, vegetable production, animal production, beekeeping, and spice production particularly pepper, ginger, white, and black cumin. The low land of the zone is dominated by semi-arid natural forests. In the zone, $51 \%$ and $49 \%$ of the population are men and women, respectively (Dessie et al. 2019; Abate et al. 2019). The survey was done in the 2018 crop season on two large pepper dominated districts specifically, Takusa and Dembia (Fig. 1).

\section{Data collection}

A combination of quantitative and qualitative data was collected from both primary and secondary sources. Primary data was collected from crop producers through a semi-structured interview and key informant's interviews. Moreover, to enrich the investigation, secondary data was collected from records of administrative offices, published and unpublished reports, journals, books, websites, and other sources relevant in this study. The interview schedule which consists of semi-structured questions was prepared in English and translated into local language to collect 


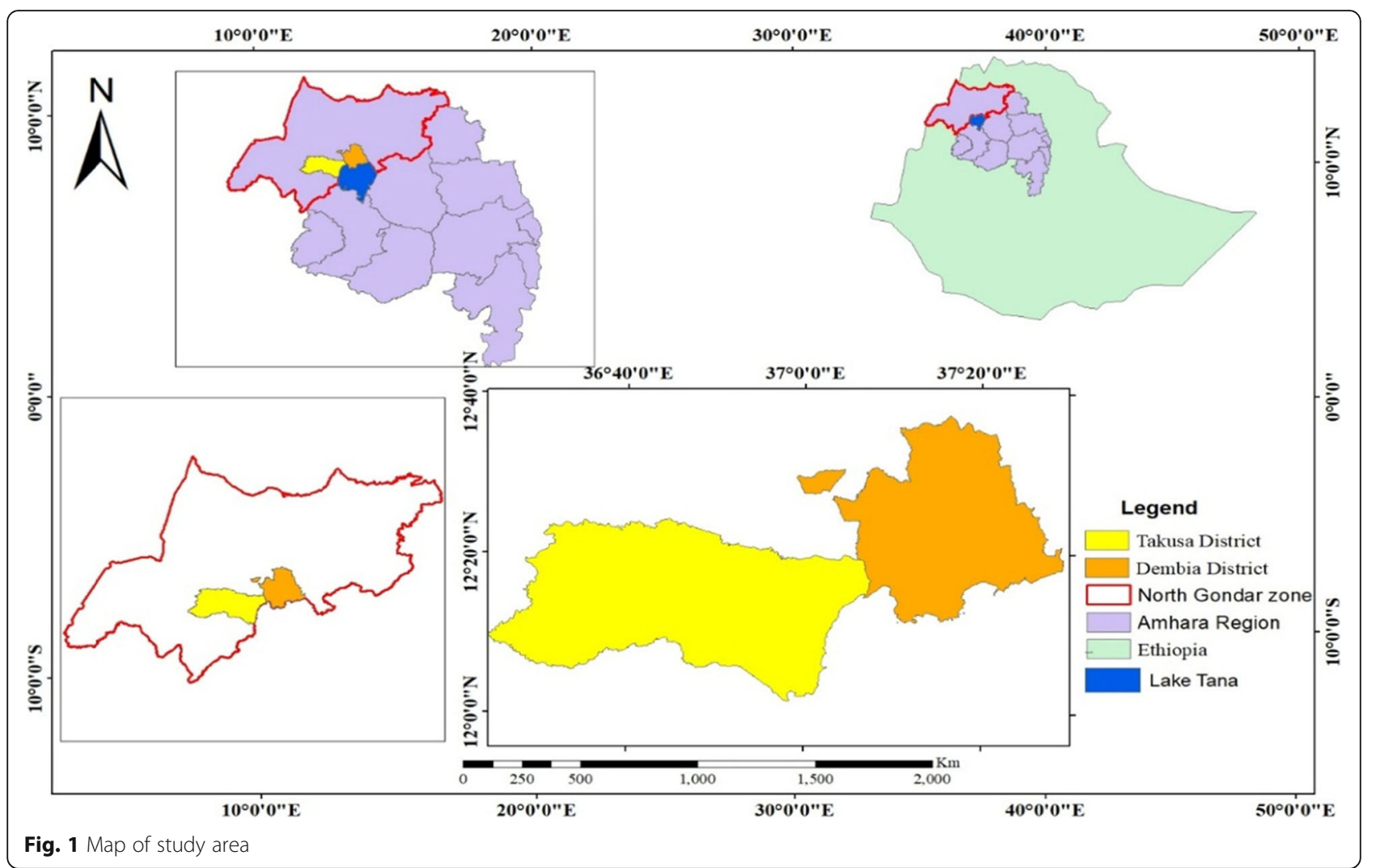

information on socio-economic, demographic and institutional characteristics of households. Furthermore, it was pre-tested, and the necessary amendments were made before the actual survey. The semistructured interviews were administered on 385 sample producers, which was the main source of a datacollection tool in the research work.

\section{Sampling design}

In order to select the sampled respondents, a multistage sampling technique was employed. In the firststage, Takusa and Dembia Districts were selected purposively due to high potentials of diversified crop production both for consumption and commercial purpose. In the second stage, eight kebeles/villages with largest crop diversification, namely, Mekonta, Chemera, Banbaro, Deber-zuria, Guramba Michael, Arebia, Achera, and Gebaba-salge were purposively selected in consultation with District Agriculture office experts due to the high potentials of crop production and best smallholder farming experience in crop diversification. In the third stage, 385 sampled crop producers were selected by using simple random sampling technique following a scientific sample size determination formula developed by (Cochran 1977).

$$
\left[\frac{Z^{2} p q}{e^{2}}\right]=\frac{1.96^{2}(0.5 * 0.5)}{0.05^{2}}=385
$$

Where $n=$ sample size; $Z=$ confidence level $(Z=$ 1.96); $p=0.5, q=1$ - $\mathrm{p}$ and $\mathrm{e}=0.05$ (error term).

\section{Data analysis}

In order to effectively handle and analyze the diverse data collected from the field and producers, a combination of descriptive statistics, inferential statistics, and econometric models was used. Chi-square test was used to assess the association of household and farm-related attributes between groups (diversifier vs. non-diversifier). The $t$ test was also used to assess mean differences between crop diversifier and non-diversifier and continues explanatory variables. Furthermore, to investigate the determinants of producer's decision and extent of crop diversification, Tobit model was used.

\section{Empirical model specification}

The extent of crop diversification can be determined by using several indices such as Herfindahl index (HI), Simpson's index (SI), Margalef index (MI), Entropy index (EI), Modified entropy index (MEI), Ogive index (OI), Composite entropy index (CEI), and Berger-Parker index (BPI). These indices have been used by many researchers to estimate the extent of crop diversification 
practices of farmers (Sisay 2016; Mussema et al. 2015; Nuru and Seebens 2008; Mesfin, Fufa, and Haji 2011; Benin et al. 2004; Abay, Bjørnstad, and Smale 2009; Ashfaq et al. 2008; Bazaz and Haq 2013; Bittinger 2010; Greene 2012; Acharya et al. 2012; Goshu, Kassa, and Ketema 2012).

However, this study used HI because it is the most commonly used index in many literature of crop diversification (Asante et al. 2018; Kanyua et al. 2013; Sichoongwe et al. 2014; De and Chattopadhyay 2010; Bittinger 2010; Malik and Singh 2002; Sisay 2016). Moreover, Theil (1967) used $\mathrm{HI}$ to determine the extent of crop diversification for the first time. Likewise, crop diversification index (CDI) was computed from Herfindahl index to measure the extent of crop diversification for all diversified farmers using a method developed by (Hirschman 1964). Hence, the extent of crop diversification was measured by CDI. The $\mathrm{CDI}$ values were obtained by subtracting the $\mathrm{HI}$ from 1 and 0 (Eq. 3). Moreover, 0 value of crop diversification index which indicates perfect specialization, and a movement towards 1 shows an increase in the extent of crop diversification (Malik and Singh 2002). Generally, the value of CDI increases with the increase in diversification and assumes 0 value when farmers grow and cultivate only one crop.

In this study, the producers basically produce diversified crops such as red pepper, teff, cumin, barley, wheat, sorghum, chickpea, garlic, finger milt, and maize at a time. To compute the Herfindahl index, the authors used the total cropped land (ha) of diversifiers and the proportion of land allocated for growing each crop (ha) in year 2018 harvested season. HI (the sum of squares of all $n$ proportions) and CDI (1HI) were computed using the formula developed by (Hirschman 1964) in Eqs. 3 and 4.

$$
P_{\mathrm{i}}=\frac{A_{\mathrm{i}}}{\sum_{i=1}^{n} A_{\mathrm{i}}}
$$

where, $\mathrm{P}_{\mathrm{i}}=$ proportion of $\mathrm{i}^{\text {th }}$ crop, $\mathrm{A}_{\mathrm{i}}=$ Area under $\mathrm{i}^{\text {th }}$ crop (ha),

$$
\begin{aligned}
& \begin{array}{r}
\left.\sum_{i=1}^{n} A_{\mathrm{i}}=\text { Total cropped land (ha) }\right) \text { and } i \\
=1,2,3 \ldots \ldots \ldots \ldots \ldots \ldots \ldots \ldots \ldots . . . n(\text { number of crop }) .
\end{array} \\
& \text { Herfinhal Index }=\mathrm{HI}=\sum_{i=1}^{n} P_{\mathrm{i}}^{2}
\end{aligned}
$$

$$
\text { Crop diversification index }=\mathrm{CDI}=1-\mathrm{HI}
$$

Crop diversification studies help to determine both factors influencing the household's decision to diversify and the extent of diversification.
Rajasekharan and Veeraputhran (2002) revealed that unlike the Probit and Logit model, a Tobit regression model is very appropriate to estimate decision and extent/density of tree growing simultaneously. Ideally, the OLS model is applicable if all households participate in all types of crop diversification, but in reality, even in this study, all households did not participate in all types of crop diversification. Hence, using OLS regression was assumed to create a sample selectivity bias because the model excludes the non-participants from the analysis. Therefore, the use of the Tobit model is appropriate because the parameter estimates will be biased and inconsistent if OLS is used. However, to mitigate this bias, the study initially used Heckman two-stage model which is developed by Heckman (1979). Selection bias was tested by including the IMR which was not significant.

Moreover, Tobit model is the most common censored regression model which helps to express the observed level in terms of an underlying latent variable. The use of the Tobit model is intuitive because the parameter estimates will be biased and inconsistent if OLS is used. The degree of bias will also increase as the number of observations that take on the value of 0 increases. The values of the parameter's coefficient from a Tobit model cannot directly give the marginal effects of the explanatory variables on the dependent variable; however, their signs only show the direction of the associations (Gujarati 2012).

However, prior to running the Tobit model, the data were estimated for multi-collinearity using the variance inflation factors and contingency coefficient to diagnose this problem and identified no problem. The parameters of the Tobit model were also estimated by using the maximum likelihood method in Stata version 14 software. The Tobit model can be specified following (Tobin 1958; Long 1997; Cameron and Trivedi 2010; Greene 2012).

$$
\begin{aligned}
& y_{i=\beta X_{i}+\varepsilon_{i}} \\
& \begin{aligned}
y_{i} & =\left\{\begin{array}{ll}
y_{i}^{*}=\beta X_{i}+\varepsilon_{i} & \text {,if } y_{i}^{*}>0 \text { (Diversifiers) } \\
0 & \text {,if } y_{i}^{*} \leq 0 \text { (Non-diversifiers) }
\end{array}, i\right. \\
& =1,2,3, \ldots \ldots ., n
\end{aligned}
\end{aligned}
$$

\section{Results and discussion}

\section{Socio-economic characteristics of households}

The total sample size of respondents handled during the survey was 385. Crop diversification levels of farmers depend on various demographic, institutional, and socioeconomic factors. This study depicted that more than three-fourth (80.52\%) of producers were crop diversifiers, and the other households (19.48\%) were non-diversifier.

The mean age of diversified producers (48.98 years) was higher than the non-diversifier (45.56 years) (Table 1). 
Table 1 Mean and proportion of producers' characteristics by crop diversification

\begin{tabular}{|c|c|c|c|c|c|}
\hline \multirow[t]{2}{*}{ Variables } & \multirow[t]{2}{*}{ Category } & \multicolumn{3}{|l|}{ Mean/proportion } & \multirow{2}{*}{$\begin{array}{l}t / x^{2} \\
\text { statistics }\end{array}$} \\
\hline & & Diversifier $(n=310)$ & Non-diversifier $(n=75)$ & Overall & \\
\hline Age & Years & $48.98(10.42)$ & $45.56(10.71)$ & $48.31(10.56)$ & $-2.536^{* *}$ \\
\hline Family size & $\mathrm{AE}$ & $3.67(1.42)$ & $3.63(1.12)$ & $3.66(1.36)$ & -0.203 \\
\hline Experience & Years & $19.29(11.65)$ & $17.13(12.06)$ & $18.87(11.75)$ & -1.429 \\
\hline Livestock owned & TLU & $6.78(5.01)$ & $6.67(10.49)$ & $8.87(46.09)$ & -0.132 \\
\hline Total land size & ha & $1.86(0.80)$ & $1.33(0.897)$ & $1.764(0.849)$ & $-5.093^{* * *}$ \\
\hline Distance to nearest market & $\mathrm{Km}$ & $5.69(5.19)$ & $3.01(3.54)$ & $5.17(5.02)$ & -0.583 \\
\hline Distance to development center & $\mathrm{km}$ & $2.49(2.89)$ & $2.69(2.36)$ & $2.54(2.79)$ & 0.550 \\
\hline \multirow[t]{2}{*}{ Sex } & Male & $300(77.92)$ & $67(17.40)$ & $367(95.32)$ & \multirow[t]{2}{*}{$7.502^{* * *}$} \\
\hline & Female & $10(2.60)$ & $8(2.08)$ & 18(4.68) & \\
\hline \multirow[t]{2}{*}{ Off/on-farm income } & Yes & 127(32.99) & $34(8.83)$ & $161(41.82)$ & \multirow[t]{2}{*}{0.473} \\
\hline & No & 183(47.53) & $41(10.65)$ & 224(58.18) & \\
\hline \multirow[t]{2}{*}{ Market information } & Yes & $206(53.51)$ & $39(10.13)$ & $245(63.64)$ & \multirow[t]{2}{*}{$5.450^{* *}$} \\
\hline & No & $104(27.01)$ & $36(9.35)$ & 140(36.36) & \\
\hline \multirow[t]{2}{*}{ Extension access } & Yes & $246(63.90)$ & $56(14.55)$ & $302(78.44)$ & \multirow[t]{2}{*}{0.785} \\
\hline & No & $64(16.62)$ & 19(4.94) & $83(21.26)$ & \\
\hline \multirow[t]{2}{*}{ Credit access } & Yes & 188(48.83) & $48(12.47)$ & 236(61.30) & \multirow[t]{2}{*}{0.286} \\
\hline & No & 122(31.69) & $27(7.01)$ & 149(38.70) & \\
\hline \multirow[t]{2}{*}{ Literacy status } & Literate & $163(42.34)$ & $36(9.35)$ & 199(51.69) & \\
\hline & Cannot read and write & 147(38.18) & $39(10.13)$ & 186(48.31) & 1.484 \\
\hline
\end{tabular}

***,**, and ${ }^{*}$ significant at 1,5 , and $10 \%$ level respectively. Results in parenthesis are percentage or standard deviation

The result of $t$ test indicates that age was statistically significant at $5 \%$ significance level. This implies that as compared to younger households, older households grow a variety of crops on a given piece of land due to their best farming experience. This finding is in line with previous studies (Asante et al. 2018; Lemi 2009; Enete and Igbokwe 2009).

In Ethiopia, the mean landholding size of farmer at the country level is 1.02 ha per household (Teshome, 2014). However, mean landholding size of farmer varies across different portions of Ethiopia. For instance, the mean landholding size of household in the study area is 1.76 ha per household. In the study area, the mean farming land of diversifier household (1.86 ha per household) was higher than non-diversifier (1.33 ha per household) (Table 1). The result of $t$ test indicates that total farming land size of farmers was statistically significant at $1 \%$ significance level. This means total farming land of households had a direct contribution to growing a variety of crops for livelihood's improvement through income and crop diversification. This result is consistent with Asante et al. 2018; Mussema et al. 2015; Huang et al. 2014; Kanyua et al. 2013; Sichoongwe et al. 2014; Mekuria and Mekonnen 2018, who reported that the practice of crop diversification increased with total farmland. Moreover, $77.92 \%$ and $17.40 \%$ of male-headed producers were diversifiers and non-diversifiers, respectively. The result of chi-square test shows that sex was statistically significant at $1 \%$ significance level. This implies that as compared to female-headed, male-headed households can grow multiple crops on a given piece of land due to inequality of having and accessing of factors of production. This finding confirmed with the results of previous studies (Demissie and Legesse, 2013 and Lemi, 2009).

Furthermore, $53.51 \%$ and $10.13 \%$ of diversifier and non-diversifier were accessed market information, respectively. On the other hand, $27.01 \%$ and $9.35 \%$ of diversifier and non-diversifiers were not accessed market information, respectively. The result of chi-square test indicates market information was statistically significant at 5\% significance level. This implies that market information can decrease the uncertainty of the producers associated with crop diversification. These findings are consistent with previous studies (Mesfin, Fufa, and Haji 2011; Mussema et al. 2015).

Household's land allocation for growing diversified crops The survey result presented in Fig. 2 revealed that producers allocated their total land for growing various crops such as red pepper production (19.32\%), teff (17.61\%), maize (12.5\%), chickpea (11.36\%), sorghum $(9.10 \%)$, barley $(6.82 \%)$, garlic $(6.25 \%)$, cumin $(5.68 \%)$, and other crops $(11.36 \%)$. This implies most producers 


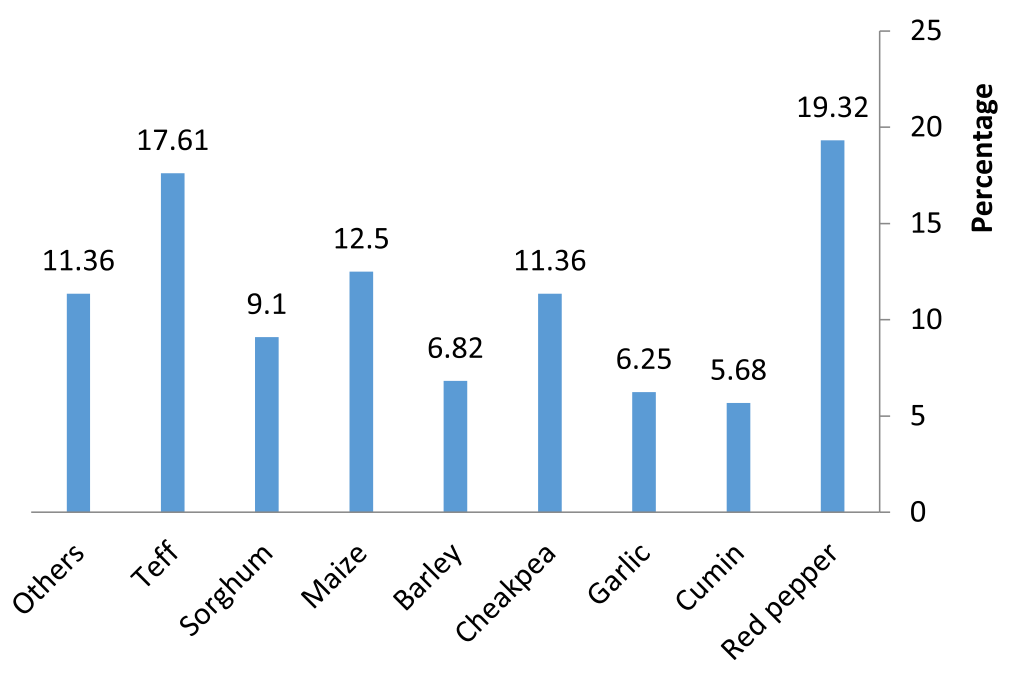

Types of crop grown in year, 2018

Fig. 2 Crop distribution in the study area

practiced and used crop diversification as a strategy for risk minimization and income diversification, which in turn reduced food insecurity and poverty status of most rural households. This finding is in line with the previous studies (Lemi 2009; Sisay 2016; Mekuria and Mekonnen 2018). Furthermore, households with large landholding willing and able to grow a diverse set of crops reduce the probability to fall into poverty (Michler and Josephson 2017).

\section{The distribution of crop diversification index}

The result presented in Fig. 3 indicated that the mean crop diversification index was 0.769 with a standard deviation of 0.142 . This implied there are high levels of crop diversification among farmers. Hence, the mean index in this study was almost comparable with the findings of Mekuria and Mekonnen 2018 and Asante et al. 2018 who found 0.57 and 0.59 in highland of Ethiopia and Ghana, respectively. Figure 3 also depicted that the crop diversification index was normally distributed and moderately skewed to the right suggesting that most households were crop diversifier. It also revealed that $92.46 \%$ of the households having indices 0.5 and above suggest a high level of crop diversification among farmers. This study, in line with Mekuria and Mekonnen 2018, confirmed that more than three-fourth (79\%) of households had an index of 0.5 and above. Moreover, the estimated crop diversification index was statistically significant among diversifiers at $1 \%$ significant level. Michler and Josephson (2017) also confirmed that a $10 \%$ increment of crop diversification index decreases the probability of being poor by $17.5 \%$.

\section{Determinants of crop diversification: estimated through Tobit model}

The results of the Tobit model are presented in Table 2. The test for multicolinearity revealed that there was no multicollinearity among the explanatory variables. The chi-square of the Tobit regression model indicates that the overall goodness of fit of the model and it was statistically significant at $1 \%$ probability level. The model results also indicated that all the significant explanatory variables, which affected the probability of households' decision and extent of crop diversification. The model output suggested that variables such as the size of farmland, sex, age, land fragmentation, distance to development center, market distance, and non-/off-farm income participation were the major factors that significantly affected decision and extent of crop diversification simultaneously.

The findings of this study revealed that size of farm landholding affected crop diversification decision and extent of the households positively and significantly at $1 \%$ level of significance. As the size of farm landholding increases by one hectare, the probability of a farmer to participate in crop diversification and the numbers of crops a farmer will grow increase by $11 \%$ and $3 \%$, respectively. This implies that large farm landholding may allow households to allot their land to grow a variety of cereal crops than smaller farm landholders. This finding, in line with the previous studies, revealed that land size positively and significantly affected crop diversification (Benin et al. 2004; Ashfaq et al. 2008; Abay, Bjørnstad, and Smale 2009; Bonham et al. 2012). This result is also consistent with recent findings (Makate et al. 2016; Mussema et al. 2015; Kanyua et al. 2013; Sichoongwe 2014; Huang et al. 2014) reporting that an increase in the 


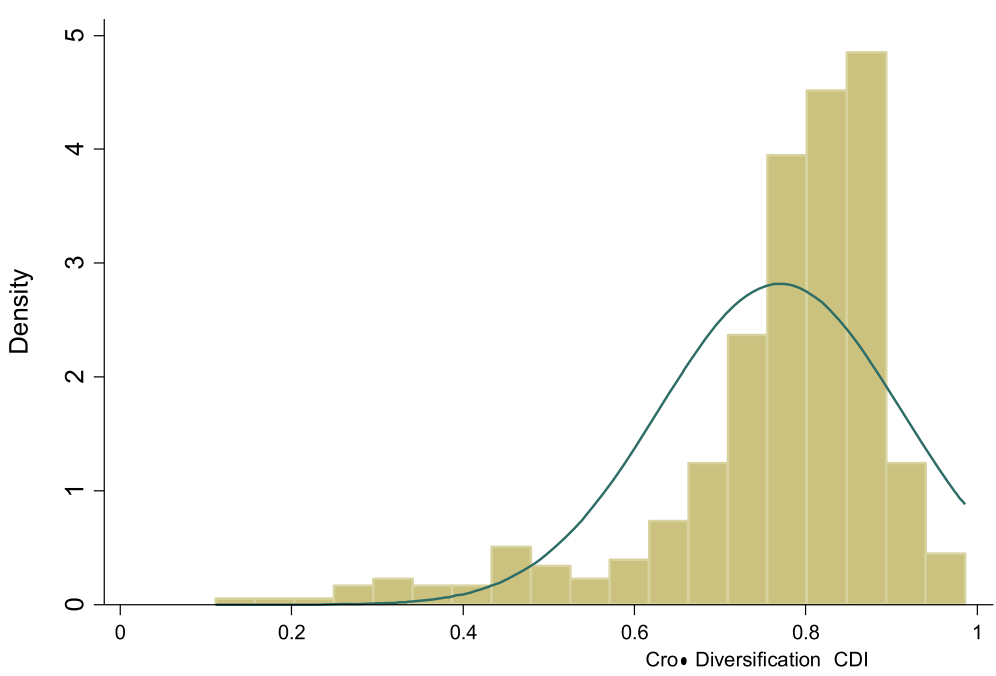

Fig. 3 Mean of household's crop diversification index

availability of farmland leads farmers to practice crop diversification.

Sex of household positively and significantly affected crop diversification decisions and extent at 10\% and 1\% level of significance, respectively. As compared to female-headed households, in the male-headed households the probability to participate in crop diversification activities and the number of crops a farmer grow increase by $15 \%$ and $3 \%$, respectively. This implies maleheaded households are risk-takers, hold more resource, and more likely to grow multiple crops for improving their family livelihoods than female-headed. This finding is consistent with the finding of Abay, Bjørnstad, and Smale (2009) who reported that unlike female-headed,

Table 2 Tobit regression result on status and intensity of crop diversification

\begin{tabular}{|c|c|c|c|c|c|}
\hline Variables & Coefficient & Std. Err. & $t$ value & Probability coefficient & Intensity coefficient \\
\hline Age of household (year) & $0.001^{* * *}$ & 0.0004 & 2.59 & $0.002^{* * *}$ & $0.0008^{* * *}$ \\
\hline Sex (1 = male, 0 otherwise) & $0.05^{* *}$ & 0.02 & 2.46 & $0.15^{*}$ & $0.03^{* * *}$ \\
\hline Literacy status ( 1 = literate, 0 otherwise) & 0.01 & 0.007 & 1.39 & 0.03 & 0.007 \\
\hline Farm experience (year) & -0.0005 & 0.0004 & -1.29 & -0.001 & -0.0003 \\
\hline Family size (AE) & -0.004 & 0.003 & -1.29 & -0.01 & -0.003 \\
\hline Land size & $0.05^{* * *}$ & 0.005 & 9.39 & $0.11^{* * *}$ & $0.03^{* * *}$ \\
\hline Livestock holding (TLU) & -0.00001 & 0.00001 & -0.77 & -0.00003 & $-9.65 e-06$ \\
\hline Fragmentation (number) & $-0.02^{* * *}$ & 0.005 & -4.45 & $-0.06^{* * *}$ & $-0.02^{* * *}$ \\
\hline Fertility of soil (( 1 = fertile, 0 otherwise) & -0.003 & 0.011 & -0.29 & -0.01 & -0.002 \\
\hline Distance to development center $(\mathrm{km})$ & $-0.002^{*}$ & 0.001 & -1.76 & $-0.005^{*}$ & $-0.002^{*}$ \\
\hline Access to extension( 1 = yes, 0 otherwise $)$ & -0.02 & 0.010 & -1.42 & -0.03 & -0.01 \\
\hline Access to credit (( $1=$ yes, 0 otherwise $)$ & -0.007 & 0.008 & -0.94 & -0.02 & -0.005 \\
\hline Market information ( 1 = yes, 0 otherwise) & 0.005 & 0.009 & 0.60 & 0.01 & 0.004 \\
\hline Market distance (km) & 0.003 & 0.0008 & 3.46 & $0.01^{* * *}$ & $0.002^{* * *}$ \\
\hline Cooperative membership ( 1 = yes, 0 otherwise) & 0.007 & 0.008 & 0.92 & 0.02 & 0.005 \\
\hline Participation of off income ( 1 = yes, 0 otherwise) & -0.03 & 0.008 & -3.86 & $-0.07^{* * *}$ & $-0.02^{* * *}$ \\
\hline Constant & 0.68 & 0.028 & 24.26 & & \\
\hline & \multicolumn{5}{|c|}{$\begin{array}{l}\text { Number of obs }=385 \\
\text { LR } \text { chi }^{2}(16)=149.52^{* * *} \\
\text { Pseudo } R^{2}=-0.3166 \\
\text { Log likelihood }=310.92\end{array}$} \\
\hline
\end{tabular}


male-headed households positively and significantly affected the barley variety diversification in Ethiopia. Asante et al. 2018 also confirmed that male-headed households were more inclined to increase the extent of diversifying than female farmers. Likewise, Demissie and Legesse (2013) stated that due to cultural, religious, and financial constraints, female-headed households had fewer roles in income diversification. Moreover, Lemi (2009) revealed that large dependents and femaleheaded characterized poor farm households in rural Ethiopia. Furthermore, Shezongo-Macmillan (2005) revealed that as compared to male-headed household, female-headed households were less responded to crop diversification in Zambia due to inequality of having and accessing of resources. However, studies (Rehima and Dawit 2012; Rehima et al. 2013; Sisay 2016) indicated that female-headed households positively affected the probability of crop diversification.

Walking distance from residence to the development center is a proxy variable of extension service and significantly and negatively affected crop diversification decision and intensity of farmers at $10 \%$ levels of significance. The results showed that as the walking distance to the development centers increases by $1 \mathrm{~km}$, the likelihood of a farmer to participate in crop diversification and the number of crops a farmer will grow decrease by $0.5 \%$ and $0.2 \%$, respectively. This implies farmers who are far away from development centers incurred high transportation costs, poor access of extension advice and input supplies such as improved seeds, fertilizers, and farming tools. As a result, the extent of crop diversification and production for commercial purposes declines. This result is consistent with the previous finding of Sisay (2016) who reported that the walking distance from residence to the development center negatively and significantly affected the decision and extent of crop diversification.

Distance from the market has a positive and significant effect on crop diversification at $1 \%$ significance level. The results of this study showed that an increase of a $1 \mathrm{~km}$ walking distance to the market leads to increase the likelihood of households participating in crop diversification by $1 \%$ and the number of crops a farmer will grow also increase by $0.2 \%$. This implies farmers who were far from the market incurred higher transaction costs for getting information, technology, and industrial consumable goods and services. As a result, the household's decision and intensity of crop diversification increase to meet and improve their family consumption and nutritional needs. The result also implies those farmers who are close to urban market tend to allocate more farmland for the production of cash and commercial crops while those who are far away from a market tend to allot much of their farmland for the production of staple (non-cash) crops for consumption and subsistence purpose. This finding, in line with the findings of recent studies (Mussema et al. 2015; Sichoongwe et al. 2014; Ibrahim et al. 2009; Nuru and Seebens 2008), revealed that market distance had a positive and significance effect on household's crop diversification decision and extents because they entirely produced staple crops for the purpose of family consumption. Likewise, Kankwamba, Mapila, and Pauw (2012) stated that farmers located far away from markets are found to diversify crops to meet their wide subsistence and nutritional needs. However, some studies indicated that market distance negatively and significantly influenced crop diversification (Sisay 2016).

The age of households was positively and significantly associated with the decision and intensity of crop diversification at $1 \%$ significance level. As an additional year added to the age of the household head, the likelihood to participate in crop diversification activities and the number of crops a farmer will grow increased by $0.2 \%$ and $0.08 \%$, respectively. This implies older farmers can reduce production adversity by growing multiple crops on a given piece of land, and their decision and intensity of crop diversification were also determined by their past production experience. This result confirmed with the findings of Asante et al. (2018) and Lemi (2009) who revealed that age of households positively and significantly affected crop diversification. Likewise, Enete and Igbokwe (2009) also confirmed that older households were more likely to produce and sell various crops.

Land fragmentation affected negatively and significantly households' decision and intensity of crop diversification at $1 \%$ significance level. An addition of one plot led to decrease the likelihood of households participating in crop diversification by $6 \%$, and the number of crops a farmer will grow also decreased by $2 \%$. This implies that farmers who operate on a different number of farm plots maintained lower crop diversity, perhaps due to similar soil and agro-ecological zone among plots, which lead to growing similar and high-value crops either for consumption or commercial purposes across different plots. The findings of this study are in line with a recent study of Sisay (2016) who stated that the numbers of fragmented land had a negative and significant effect on crop diversification. However, inconsistent to this finding, some previous studies showed that the number of fragmented land and fragmentation index positively affected agricultural diversification (Abay, Bjørnstad, and Smale 2009; Mussema et al. 2015; Mesfin, Fufa, and Haji 2011; Rehima et al. 2013; Nagarajan, Smale, and Glewwe 2007).

The coefficient for household participation in off- 1 non-farm income activities negatively and significantly affected the probability and intensity of crop diversification at $1 \%$ level of significance. In those households that participated in off-/non-farm activities, the likelihood of farmer's participating in crop diversification and the numbers of crops grow by farmers decrease by $7 \%$ and 
$2 \%$, respectively. The result suggests that participation on off-/non-farm income activities provide as a source of income to households and their livelihoods as a result negatively contributed to the practice of crop diversification. However, Asante et al. (2018) revealed that offfarm income had a positive and significant effect on the crop-livestock diversification.

\section{Conclusion and recommendations}

The diversified farming system remains a source of income, risk reduction strategy, and means to improve the livelihoods of households in northwestern Ethiopia. Crop diversification strategy also plays a significant role in households particularly on the source of income and a means for nutritional improvement. It is also used as a mechanism of risk reduction strategy to obtain food and income from multiple crop sources. However, various socio-economic, demographic, and institutional factors influenced the household's decision and intensity of crop diversification. Our results revealed that the majority of smallholder farmers (92\%) has a crop diversification index of above 0.5 , and the average crop diversification index was 0.769 implying high levels of crop diversification. The results of inferential statistics such as chisquare and $t$ test revealed that various socio-economic parameters such as age, sex, market information, and farmland size were had a significant association and mean difference between groups. Moreover, the result of Tobit regression model indicated that various policyrelevant variables such as age, sex, land size, distance to development center, market distance, and land fragmentation had a significant influence on the status and extent of crop diversification simultaneously. For instance, an older male headed household has more resource and farming experience in crop diversification. Likewise, the smallholder farmer's status and intensity of crop diversification was found to increase with more farm land owned and near market distance. However, it was declined with more land fragmentation and participation in off-/non-farm activities due to similar agro-ecological zone and high contribution of off-/non-farm activities on enhancing household's income source. Given the potential and significant role of crop diversification to improve the livelihood of most smallholder farmers, the following implication has given to the development of the practice of crop diversification strategy. In most developing countries, smallholder farmers provide and supply food for most country citizens. Therefore, the government should consider and undertake policies that will improve smallholder farmers' access to and control over land because it allows farmers to grow multiple crops for the purpose of enhancing food and nutrition security status and poverty reduction. As the farmers who are far away from markets, they are willing and able to diversify crops for nutritional and consumption purposes. If markets are brought closer to farmer, they will diversify crops for commercial purposes. It implies that the ability of households to adopt new agricultural technology such as crop varieties and inorganic fertilizers are related to the market. Hence, the government should facilitate and improve the markets and road infrastructure by bringing closer to the farmers. Moreover, in most developing countries including Ethiopian, the resources are mainly undertaken by male-headed farm households. Therefore, there should be policies that enhance the equitable distribution of resources and involvement of female-headed farm households in crop diversification strategy. Generally, this study provides information on why, how, and what smallholder farmers diversify on agricultural fields. Likewise, the information generated could help a number of organizations including research and development organizations, academicians, traders, producers, policy-makers, extension service providers, government, and non-governmental organizations to assess their activities and redesign their mode of operations and ultimately influence the design and implementation of policies and strategies on agricultural sectors. Further research should be conduct on the impacts of livelihood diversification strategies on household's food security status.

\section{Abbreviations}

AE: Adult equivalent; BPI: Berger-Parker index; CDI: Crop diversification index; CEl: Composite entropy index; CSA: Central Statistical Agency; e: Error; El: Entropy index; FAO: Food and Agricultural Organization; HI: Herfindahl index; IMR: Inverse Mills Ratio; MEl: Modified entropy index; MI: Margalef index; $n$ : Sample size; Ol: Ogive index; OLS: Ordinary least square; P: Probability of success: probability of failure; SI: Simpson's Index; TLU: Tropical Livestock Unit; Z: Confidence level

\section{Acknowledgements}

The author would like to thank the University of Gondar since financial support for this research was obtained from the University of Gondar. Moreover, we thank the data respondents, enumerators and district experts for their valuable response during the data collection process.

Authors' contributions

All authors read and approved the final manuscript.

\section{Funding}

Not applicable

\section{Availability of data and materials}

The author wants to declare that they can submit the data at any time based on publisher's request. The datasets used and/or analyzed during the current study will be available from the author on reasonable request

\section{Ethics approval and consent to participate}

Ethical clearance letters were collected from the University of Gondar research and community service directorate and North Gondar Zone administrative office to care for both the study participants and the researchers. During the survey, official letters were written for each district and kebele/villages/informed verbal consent was obtained from each client, and confidentiality was maintained by giving codes for each respondent rather than recording their name. Study participants were informed that clients have a full right to discontinue or refuse to participate in the study. Hence, all participants throughout the research, including survey households, 
enumerators, the supervisors, and key informants were fully informed of the objectives of the study. They were approached friendly in free moods until the end of this research

\section{Consent for publication}

Not applicable

\section{Competing interests}

The authors declare that they have no competing interests.

\section{Author details}

'Department of Agricultural Economics, College of Agriculture and Environmental Science, University of Gondar, P.O. Box 196, Gondar, Ethiopia. ${ }^{2}$ Department of Plant Science, College of Agriculture and Environmental Science, University of Gondar, Gondar, Ethiopia.

Received: 7 June 2019 Accepted: 30 October 2019

Published online: 18 December 2019

\section{References}

Abate TM, Dessie AB, Mekie TM (2019) Technical efficiency of smallholder farmers in red pepper production in North Gondar zone Amhara regional state, Ethiopia. J Econ Struct 8(1):18

Abay F, Bjørnstad A, Smale M (2009) Measuring on farm diversity and determinants of barley diversity in Tigray, northern Ethiopia. Momona Ethiopian J Sci 1(2):44-66

Abson DJ, Fraser EDG, Benton TG (2013) Landscape diversity and the resilience of agricultural returns: a portfolio analysis of land-use patterns and economic returns from lowland agriculture. Agric Food Secur 2(1):2

Acharya SP (2011) Crop Diversification in Karnataka: An Economic Analysis. UAS, Dharwad

Acharya SP, Basavaraja H, Kunnal LB, Mahajanashetti SB, Bhat ARS (2012) Growth in area, production and productivity of major crops in Karnataka. Karnataka J Agric Sci 25(4):431-436

Asante BO, Villano RA, Patrick IW, Battese GE (2018) Determinants of farm diversification in integrated crop-livestock farming systems in Ghana. Renewable Agric Food Syst 33(2):131-149

Ashfaq M, Hassan S, Naseer MZ, Baig IA, Asma J (2008) Factors affecting farm diversification in rice-wheat. Pak J Agric Sci 45(3):91-94

Barrett CB, Reardon T, Webb P (2001) Nonfarm income diversification and household livelihood strategies in rural Africa: concepts, dynamics, and policy implications. Food Policy 26(4):315-331

Bazaz NH, Haq I (2013) Crop diversification in Jammu and Kashmir: pace, pattern and determinants. IOSR J Humanities Social Sci 11(5):1-7

Benin S, Smale M, Pender J, Gebremedhin B, Ehui S (2004) The economic determinants of cereal crop diversity on farms in the Ethiopian highlands. Agric Econ 31(2-3):197-208

Bittinger AK (2010) Crop diversification and technology adoption: the role of market isolation in Ethiopia. Montana State University-Bozeman, College of Agriculture

Bommarco R, Kleijn D, Potts SG (2013) Ecological intensification: harnessing ecosystem services for food security. Trends Ecol Evol 28:230-238

Bonham CA, Gotor E, Beniwal BR, Canto GB, Ehsan MD, Mathur P (2012) The patterns of use and determinants of crop diversity by pearl millet ( Pennisetum glaucum (L.) R. Br.) farmers in Rajasthan. Ind J Plant Genet Resour 25(1):85-96

Burchfield EK, de la Poterie AT (2018) Determinants of crop diversification in ricedominated Sri Lankan agricultural systems. J Rural Stud 61:206-215

Cameron AC, Trivedi PK (2010) Microeconometrics Using Stata, Revised Edition. Stata Press, College Station

Chaplin KR, O'Rourke ME, Blitzer EJ, Kremen C (2011) A meta-analysis of crop pest and natural enemy response to landscape complexity. Ecol Lett 14:922-932

Cochran WG (1977) Sampling Techniques, 3rd edn. Wiley, New York

Davis TJ, Schirmer IA (1987) Sustainability issues in agricultural development: proceedings of the seventh agriculture sector symposium. Agricultural Sector Symposium, 7

De UK, Chattopadhyay M (2010) Crop diversification by poor peasants and role of infrastructure: Evidence from West Bengal. J Dev Agric Econ 2(10):340-350

Demissie A, Legesse B (2013) Determinants of income diversification among rural households: The case of smallholder farmers in Fedis district, Eastern Hararghe zone, Ethiopia. J Dev Agric Econ 5(3):120-128
Dessie AB, Koye TD, Koye AD, Abitew AA (2019) Analysis of red pepper marketing: evidence from northwest Ethiopia. J Econ Struct 8:24 https://doi. org/10.1186/s40008-019-0156-0

Enete AA, Igbokwe EM (2009) Cassava market participation decisions of producing households in Africa. Tropicultura 27(3):129-136

Escobal J (2001) The determinants of nonfarm income diversification in rural Peru. World Dev 29(3):497-508

FAO (2012) Crop diversification for sustainable diets and nutrition: The role of FAO's Plant Production and Protection Division. In: Technical report, Plant Production and Protection Division. United Nations, Food and Agriculture Organization, Rome

Goshu D, Kassa B, Ketema M (2012) Does crop diversification enhance household food security? Evidence from rural Ethiopia. Advan Agric Sci Engineering Res 2(11):503-515

Greene WH (2012) Econometric Analysis, 7th edn. Prentice Hall, New York

Gujarati DN (2012) Basic Econometrics. Tata McGraw Hill Education Private Limited, New York

Heckman JJ (1979) Sample selection bias as a specification error. Econometrica 47(1):153-161

Hirschman AO (1964) The paternity of an index. Am Econ Rev 54(5):761-762

Huang J-k, Jiang J, Wang J-x, L-I H (2014) Crop diversification in coping with extreme weather events in China. J Integr Agric 13(4):677-686

Ibrahim H, Rahman SA, Envulus EE, Oyewole SO (2009) Income and crop diversification among farming households in a rural area of north central Nigeria. J Tropical Agric Food Environ Exten 8(2):84-89

Johnston GW, Suzanne V, Franz RK, Melissa C (1995) Crop and farm diversification provide social benefits. Calif Agric 49(1):10-16

Kankwamba H, Mapila MATJ, Pauw K (2012) Determinants and spatiotemporal dimensions of crop diversification in Malawi. Project Report produced under a cofinanced research agreement between Irish Aid, USAID and IFPRI, Paper 3

Kanyua MJ, Ithinji GK, Muluvi AS, Gido OE, Waluse SK (2013) Factors influencing diversification and intensification of horticultural production by smallholder tea farmers in Gatanga District, Kenya. Curr Res J Soc Sci 5(4):103-111

Lemi A (2009) Determinants of income diversification in rural Ethiopia: Evidence from panel data. Ethiopian J Econ 18(1)

Lin BB (2011) Resilience in agriculture through crop diversification: adaptive management for environmental change. BioScience 61:183-193

Long JS (1997) Advanced quantitative techniques in the social sciences series, Vol. 7. Regression models for categorical and limited dependent variables. Sage Publications, Inc, Thousand Oaks

Makate C, Wang R, Makate M, Mango N (2016) Crop diversification and livelihoods of smallholder farmers in Zimbabwe: adaptive management for environmental change. SpringerPlus 5(1):1135

Malik DP, Singh IJ (2002) Crop diversification-An economic analysis. Indian J Agric Res 36(1):61-64

McDaniel MD, Tiemann LK, Grandy AS (2014) Does agricultural crop diversity enhance soil microbial biomass and organic matter dynamics? A metaanalysis. Ecol Appl 24:560-570

Mekuria W, Mekonnen K (2018) Determinants of crop-livestock diversification in the mixed farming systems: evidence from central highlands of Ethiopia. Agric Food Secur 7(1):60

Mesfin W. Fufa B, Haji J (2011) Pattern, trend and determinants of crop diversification: empirical evidence from smallholders in eastern Ethiopia. Econ Sustainable Dev 2(8):78-89

Michler JD, Josephson AL (2017) To specialize or diversify: agricultural diversity and poverty dynamics in Ethiopia. World Dev 89:214-226

Mussema R, Kassa B, Alemu D, Shahidur R (2015) Determinants of crop diversification in Ethiopia: Evidence from Oromia region. Ethiopian J Agric Sci 25(2):65-76

Nagarajan L, Smale M, Glewwe P (2007) Determinants of millet diversity at the household-farm and village-community levels in the drylands of India: the role of local seed systems. Agric Econ 36(2):157-167

Njeru EM (2016) Crop diversification: a potential strategy to mitigate food insecurity by smallholders in sub-Saharan Africa. J Agric Food Syst Comm Develop 3(4):63-69

Nuru SA, Seebens H (2008) The impact of location on crop choice and rural livelihood: evidences from villages in Northern Ethiopia. Center for Development Research (ZEF), University of Bonn, Germany

Rajasekharan P, Veeraputhran S (2002) Adoption of intercropping in rubber smallholdings in Kerala, India: a tobit analysis. Agrofor Syst 56(1):1-11 
Rehima M, Belay K, Dawit A, Rashid S (2013) Factors affecting farmers' crops diversification: Evidence from SNNPR, Ethiopia. Int J Agric Sci 3(6):558-565

Rehima M, Dawit A (2012) Red pepper marketing in Siltie and Alaba in SNNPRS of Ethiopia: factors affecting households' marketed pepper. Int Res J Agric Sci Soil Sci 2(6):261-266

Schulte LA, Niemi J, Helmers MJ, Liebman M, Arbuckle JG, James DE, Kolka RK, O'Neal ME, Tomer MD, Tyndall JC, Asbjornsen H, Drobney P, Neal J, Van Ryswyk G, Witte C (2017) Prairkie strips improve biodiversity and the delivery of multiple ecosystem services from corn-soybean croplands. Proc Natl Acad Sci U S A 114:11247-11252

Shezongo-Macmillan J (2005) Women's property rights in Zambia. Paper read at Strategic Litigation Workshop. Johannesburg, South Africa

Sichoongwe K (2014) Determinants and Extent of Crop Diversification Among Smallholder Farmers in Southern Zambia. Collaborative Masters Program in Agricultural and Applied Economics

Sichoongwe K, Mapemba L, Ng'ong'ola D, Tembo G (2014) The determinants and extent of crop diversification among smallholder farmers: A case study of Southern Province, Zambia. J Agric Sci 6:150-159

Sisay D (2016) Agricultural Technology Adoption, Crop Diversification and Efficiency of Maize-Dominated Smallholder Farming System in Jimma Zone, Southwestern Ethiopia. Haramaya University, Ethiopia

Teshome M (2014) Population growth and cultivated land in rural Ethiopia: land use dynamics, access, farm size, and fragmentation. Resour Environ 4(3):148161

Theil H (1967) Economics and information theory. North-Holland Publishing Company, Amsterdam

Tiemann LK, Grandy AS, Atkinson EE, Marin-Spiotta E, McDaniel MD, Hooper D (2015) Crop rotational diversity enhances belowground communities and functions in an agroecosystem. Ecol Lett 18:761-771

Tobin J (1958) Estimation of relationships for limited dependent variables Econometrica 26:24-36

Tscharntke T, Klein AM, Kruess A, Steffan-Dewenter I, Thies C (2005) Landscape perspectives on agricultural intensification and biodiversity - ecosystem service management. Ecol Lett 8:857-874

\section{Publisher's Note}

Springer Nature remains neutral with regard to jurisdictional claims in published maps and institutional affiliations.

\section{Submit your manuscript to a SpringerOpen ${ }^{\circ}$ journal and benefit from:}

- Convenient online submission

- Rigorous peer review

- Open access: articles freely available online

High visibility within the field

- Retaining the copyright to your article

Submit your next manuscript at $\boldsymbol{\nabla}$ springeropen.com 